\title{
Korean Organization ERP System Implementation CSFs: A Delphi Study ${ }^{\dagger}$
}

\author{
Yeong Real Kim*
}

\begin{abstract}
This study focused on the factors that are critical to Enterprise Resource Planning (ERP) system implementation success. This study employed a Delphi panel to explore the characteristics of ERP project success. The expert panel was comprised of executives from Korean organizations who had participated in and were experienced with ERP implementation projects. The two round Delphi study found the importance of senior management involvement/top management support in project. Additionally, the study found that the same Critical Success Factors(CSFs) existing in large-sized Korean organizations are also applicable to small or mid-sized Korean organizations.
\end{abstract}

Key Words : ERP, CSF, Delphi study, Implementation

\section{Introduction}

The market for Enterprise Resource Planning (ERP) software has grown dramatically since 1990. $\mathrm{ERP}$ is defined as an integrated, multi-dimensional system that encompasses all functions of an organization, including planning, control, and global optimization of the supply chain using state of the art information technology tools(Jarrar, Almudimigh, and Zairi, 2000). There are many reasons provided in the literature for the popularity and adoption of ERP. Davenport(1998) argued that some executives implement ERP to inject discipline in their organizations and eliminate redundant data and costly legacy code maintenance expenses. Allen, Kern, and Havenhand(2002) added that ERP is implemented by organizations to increase decision-making speed, to improve the control of operations and costs, and to improve enterprise

† 본 연구는 2011년도 충북대학교 기성회 연구비 지원금에 의하 여 연구되었음.

* Department of Management Information Systems Chungbuk National University(yrkim@cbnu.ac.kr) wide information dissemination.

This study focused on the factors that are critical to ERP implementation success. The expert panel was comprised of executives from Korean organizations who had participated in and were experienced with ERP implementation projects. Specifically, the expert panel was assembled to review a list of ERP implementation critical success factors(CSFs) that were developed by the researcher. The expert panel was asked to add additional critical ERP success factors to the list if necessary, and then rank them in order of importance. Through subsequent rounds of the study, the expert panel was asked to refine the list and their ranking based on feedback from other members of the expert panel. Last, they were asked to distinguish between factors for small and mid-sized organizations (under \$200 million in annual revenues) and large organizations $(\$ 200$ million and greater in annual revenues). This study addressed the following questions.

a. What are the specific ERP implementation critical success factors that lead to implementation 
success for Korean large-sized Organizations?

b. Are there differences in ERP implementation critical success factors between small or mid-sized Korean organizations and large Korean organizations?

\section{Critical Success Factors(CSFs)}

The literature shows lots of information that addresses ERP implementation CSFs. In order to analyze ERP implementation CSFs, the researcher undertook an analysis of 30 distinct sources and located 22 different CSFs raised by the authors of literature reviewed. The literature review conducted of ERP project CSFs across 30 sources listed 22 project success factors. The 10 most frequently mentioned CSFs across all implementation categories are listed in $\langle$ Table 1$\rangle$.

Table 1. Critical Success Factors Appearing in Literature

\begin{tabular}{|c|l|c|}
\hline Rank & \multicolumn{1}{|c|}{ Critical Success Factors } & $\begin{array}{c}\% \text { of } \\
\text { Mentions }\end{array}$ \\
\hline 1 & $\begin{array}{l}\text { Senior Management } \\
\text { Support/Involvement }\end{array}$ & 82 \\
\hline 2 & Skilled/Empowered Project Team & 75 \\
\hline 3 & $\begin{array}{l}\text { Commitment to Change } \\
\text { Management }\end{array}$ & 68 \\
\hline 4 & $\begin{array}{l}\text { Commit to Business Process } \\
\text { Reengineering }\end{array}$ & 66 \\
\hline 5 & Effective Project Communication & 59 \\
\hline 6 & $\begin{array}{l}\text { Develop a Detailed Project Plan } \\
7\end{array}$ & Strong Project Management \\
\hline 8 & $\begin{array}{l}\text { Effective Knowledge Transfer to } \\
\text { End Users }\end{array}$ & 46 \\
\hline 9 & $\begin{array}{l}\text { Develop Clear Vision, Objectives } \\
\text { and Mission }\end{array}$ & 34 \\
\hline 10 & $\begin{array}{l}\text { Engage Effective External } \\
\text { Resources }\end{array}$ & 34 \\
\hline
\end{tabular}

In <Table 1>, Critical success factors are rank listed by the percentage of mentions they appeared in the literature reviewed.

\section{Research Design Strategy}

The Delphi method was chosen as the underlying research methodology employed for this study. The Delphi method is a qualitative research tool that seeks the opinions of an expert panel concerning the relevant research questions. The ERP industry is a relatively young industry that came to prominence in the early 1990s. Fowles (1978) posited that the testimony of experts, as under the Delphi method, is particularly applicable in fields that have not yet developed their own scientific laws. Fowles(1978) listed the following Delphi steps as critical: (a) panel selection, (b) first round Delphi questionnaire development, (c) questionnaire piloting, (d) forwarding the first round questionnaires, and (e) collection and analysis of first round questionnaire results. Subsequent study rounds continued by following steps (d) and (e) until the survey results stabilized.

The study was conducted over a number of weeks with the use of iterative questionnaire rounds. The questionnaire process was administered through the use of Internet-based, web survey tool. If participants did not have Internet access to complete the survey, they were given the option to hand complete and submit surveys via mail. The survey questionnaires in this study consisted of a combination of closed-ended and open-ended questions. Delphi participants were asked to rank order ERP critical success factors so that a group composite ranked list could be determined. Both open and closed ended question responses were accumulated and collated by the researcher and returned in later, iterative rounds to the Delphi panel. Based on the information provided, the participants were asked to revisit responses after reviewing the responses and, reviewing the responses and comments of other panel members. 


\section{Presentation and Analysis of Data}

\subsection{Round One Survey Process}

Round One survey was forwarded to 20 survey participants via an e-mail cover letter and a link to the web-based survey. After a two-week period, 16 completed surveys were returned, yielding a 80 $\%$ response rate. Multiple reminder messages were sent to the survey participants to encourage a higher response rate. The survey was constructed not only to gain information regarding the principal questions of this research, but to also compile demographic data about the survey participants Round one survey participants consisted of two chief information officers, 10 vice-presidents of information technology department, 10 directors of business information service department. All survey participants had participated in at least one ERP implementation.

Round one survey explored the survey participants' opinions as to ERP implementation critical success factors. The researcher provided the survey participants with an alphabetized list of 10 ERP implementation critical success factors as shown in $\langle$ Table 1$\rangle$. The survey instrument was posed as follows:

The following items are some examples (list in alphabetical order) of possible ERP implementation critical success factors. Please add any additional factors that you believe are critical to ERP implementation success.

a. Commitment to business process reengineering

b. Commitment to change management

c. Development of a clear vision, objectives and mission

d. Development of a detailed project plan

e. Effective knowledge transfer to end users

f. Effective project communication

g.. Involvement of effective external resources

h. Involvement of senior management/top management support i. Use of a skilled/dedicated/empowered project team

j. Use of strong project management skills

The survey participants were asked to add additional ERP implementation critical success factors per their experiences. As a result, the survey participants who responded suggested additional 18 ERP implementation critical success factors to consider. Next the survey participants were asked to select $10 \mathrm{ERP}$ implementation critical success factors from the list of possible 28 success factors. The survey instrument was posed as follows:

Please review the previous list(both the items provided you and those you added) and compile a consolidated list of the top $10 \mathrm{ERP}$ implementation critical success factors. The ERP implementation critical success factors should be ranked from most important to least important.

$<$ Table 2> lists the ERP implementation critical success factors as selected by the survey participants.

Table 2. ERP Implementation Critical Success Factors (CSFs)

\begin{tabular}{|l|c|c|}
\hline \multicolumn{1}{|c|}{ ERP CSFs } & Total & $\%$ \\
\hline $\begin{array}{l}\text { 1. Involvement of senior } \\
\text { management/Top management } \\
\text { support }\end{array}$ & 14 & 87.5 \\
\hline $\begin{array}{l}\text { 2. Use of a skilled/empowered } \\
\text { project team }\end{array}$ & 12 & 75.0 \\
\hline $\begin{array}{l}\text { 3. Commitment to business } \\
\text { process reengineering }\end{array}$ & 10 & 62.5 \\
\hline 4. Effective project communication & 10 & 62.5 \\
\hline $\begin{array}{l}\text { 5. Commitment to change } \\
\text { management }\end{array}$ & 9 & 56.3 \\
\hline $\begin{array}{l}\text { 6. Involvement of effective } \\
\text { external resources }\end{array}$ & 8 & 50.0 \\
\hline $\begin{array}{l}\text { 7. Development of a clear vision, } \\
\text { objectives and mission }\end{array}$ & 8 & 50.0 \\
\hline $\begin{array}{l}\text { 8. Use of strong project } \\
\text { management skills }\end{array}$ & 6 & 37.5 \\
\hline $\begin{array}{l}\text { 9. Effective knowledge transfer to } \\
\text { end-users }\end{array}$ & 6 & 37.5 \\
\hline $\begin{array}{l}\text { 10. Development of a detailed } \\
\text { project plan }\end{array}$ & 5 & 31.3 \\
\hline
\end{tabular}

Note: \% represents the frequency that critical success factor was mentioned by a survey participant 
The additional series of questions in the Round One survey pertained to ERP implementation critical success factors in small or mid-sized organizations. Small or mid-sized organizations became important new targets in the marketing of ERP software. (Small or Mid-sized organizations were defined as organizations with annual revenues of less than \$200 million.) The justification behind the inclusion of these questions in the Round One survey was to determine if the survey participants would identify different ERP implementation critical success factors if they knew that the implementing organization was categorized as a small or mid sized organization. The researcher referred the Delphi participants back to the ranked list of ERP implementation critical success factors formulated previously. The Dephi participants were permitted to add new critical success factors, if necessary, when answering the following question:

Many larger organizations (annual sales greater than \$200 million) have already implemented ERP and increasingly software vendors are focusing on selling to small or mid-sized organizations (annual sales of less than \$200 million). When focusing exclusively on small or mid sized organizations, please rank ERP implementation critical success factors from most important to least important.

Detailed analysis (as shown in <Table 3>) of the responses showed that seven different ERP implementation success factors were listed as the most important critical success factors by the survey participants.

In fact, the same ten ERP implementation critical success factors were listed by the participants, although in a different order, in both large-sized organizations and in small or mid-sized organizations. It appears that the survey participants did not see many differences in ERP implementation critical success factors in small or mid-sized versus large-sized organizations.

At the conclusion of the Round One survey process, the researcher compiled the results and
Table 3. ERP Implementation CSFs in Small or Mid-Sized Organizations

\begin{tabular}{|l|c|c|}
\hline \multicolumn{1}{|c|}{ ERP CSFs } & Total & $\%$ \\
\hline $\begin{array}{l}\text { 1. Involvement of senior } \\
\text { management/Top management } \\
\text { support }\end{array}$ & 13 & 81.3 \\
\hline $\begin{array}{l}\text { 2. Use of a skilled/empowered } \\
\text { project team }\end{array}$ & 12 & 75.0 \\
\hline 3. Effective project communication & 12 & 75.0 \\
\hline $\begin{array}{l}\text { 4. Development of a clear vision, } \\
\text { objectives and mission }\end{array}$ & 10 & 62.5 \\
\hline $\begin{array}{l}\text { 5. Commitment to business } \\
\text { process reengineering }\end{array}$ & 10 & 62.5 \\
\hline $\begin{array}{l}\text { 6. Effective knowledge transfer to } \\
\text { end-users }\end{array}$ & 9 & 56.3 \\
\hline $\begin{array}{l}\text { 7. Use of strong project } \\
\text { management skills }\end{array}$ & 9 & 56.3 \\
\hline $\begin{array}{l}\text { 8. Involvement of effective } \\
\text { external resources }\end{array}$ & 7 & 43.8 \\
\hline $\begin{array}{l}\text { 9. Commitment to change } \\
\text { management }\end{array}$ & 67.5 \\
\hline $\begin{array}{l}\text { 10. Development of a detailed } \\
\text { project plan }\end{array}$ & 8 \\
\hline
\end{tabular}

provided the data back to the survey participants. To ensure the anonymity of the Delphi process, all participants were assigned letters of the alphabet (instead of using their names) for use as their responses were being compiled. To ensure the integrity of the survey, the respondents' exact answers were provided in the feedback documents with no editing.

\subsection{Round Two Survey Process}

Round Two surveys were forwared to the 16 survey participants of the Round One survey. After a two-week period and several follow-up e-mails to the survey participants to encourage a higher response rate, 14 responses to the Round Two survey were received. This response yielded an 87.5\% Round Two response rate. <Table 4> represents the Round Two responses. Again, the survey participants identified the importance of the involvement of senior management/Top management 
Table 4. Round Two ERP Implementation Critical Success Factors (CSFs)

\begin{tabular}{|l|c|c|}
\hline \multicolumn{1}{|c|}{ ERP CSFs } & Total & $\%$ \\
\hline $\begin{array}{l}\text { 1. Involvement of senior } \\
\text { management/Top management } \\
\text { support }\end{array}$ & 14 & 100.0 \\
\hline $\begin{array}{l}\text { 2. Use of a skilled/empowered } \\
\text { project team }\end{array}$ & 12 & 85.7 \\
\hline $\begin{array}{l}\text { 3. Commitment to business } \\
\text { process reengineering }\end{array}$ & 12 & 85.7 \\
\hline $\begin{array}{l}\text { 4. Effective project } \\
\text { communication }\end{array}$ & 11 & 78.6 \\
\hline $\begin{array}{l}\text { 5. Effective knowledge transfer } \\
\text { to end-users }\end{array}$ & 10 & 71.4 \\
\hline $\begin{array}{l}\text { 6. Development of a clear } \\
\text { vision, objectives and mission }\end{array}$ & 10 & 71.4 \\
\hline $\begin{array}{l}\text { 7. Commitment to change } \\
\text { management }\end{array}$ & 9 & 64.3 \\
\hline $\begin{array}{l}\text { 8. User involvement and scope } \\
\text { control }\end{array}$ & 9 & 64.3 \\
\hline $\begin{array}{l}\text { 9. Use of strong project } \\
\text { management skills }\end{array}$ & 8 & 50.0 \\
\hline $\begin{array}{l}\text { 10. Involvement of effective } \\
\text { external resources }\end{array}$ & 7.1 \\
\hline
\end{tabular}

support. In Round Two, $100 \%$ of the survey participants listed this factor as an important ERP implementation critical success factor.

The Round Two survey process also addressed the open-ended responses provided by the survey participants regarding their reasoning in selecting the ERP implementation critical success factors. The researcher was interested in gaining insight into the survey participants' reasoning for ranking ERP implementation critical success factors. Again, the ability to gain strong support from the senior management is listed as an important ERP implementation success criterion. Commitment to change management, User involvement and scope control, and empowering end-users were mentioned frequently in the open-ended responses.

The Round Two survey also addressed ERP implementation critical success factors that exist in small or mid-sized organizations. With this question, the researcher was interested in determining if the participants believed there were significant differences between ERP implementation critical success factors in small or mid-sized organizations and large-sized organizations. As shown in <Table $5>$, involvement of senior management/Top management support and the use of skilled/ empowered project team were chosen with 100\% frequency by the survey participants.

Table 5. Round-Two ERP Implementation CSFs in Small or Mid-sized Organizations

\begin{tabular}{|l|c|c|}
\hline $\begin{array}{l}\text { ERP in Small or Mid-Sized } \\
\text { Organizations }\end{array}$ & Total & $\%$ \\
\hline $\begin{array}{l}\text { 1. Involvement of senior } \\
\text { management/Top management } \\
\text { support }\end{array}$ & 14 & 100.0 \\
\hline $\begin{array}{l}\text { 2. Use of a skilled/empowered } \\
\text { project team }\end{array}$ & 14 & 100.0 \\
\hline $\begin{array}{l}\text { 3. Effective project } \\
\text { communication }\end{array}$ & 13 & 87.5 \\
\hline $\begin{array}{l}\text { 4. Commitment to business } \\
\text { process reengineering }\end{array}$ & 12 & 85.7 \\
\hline $\begin{array}{l}\text { 5. Effective knowledge transfer } \\
\text { to end-users }\end{array}$ & 11 & 71.4 \\
\hline $\begin{array}{l}\text { 6. Involvement of effective } \\
\text { external resources }\end{array}$ & 11 & 50.0 \\
\hline $\begin{array}{l}\text { 7. Development of a clear vision, } \\
\text { objectives and mission }\end{array}$ & 10 & 71.4 \\
\hline $\begin{array}{l}\text { 8. Commitment to change } \\
\text { management }\end{array}$ & 94.3 \\
\hline $\begin{array}{l}\text { 9. User involvement and scope } \\
\text { control }\end{array}$ & 94.3 \\
\hline $\begin{array}{l}\text { 10. Use of strong project } \\
\text { management skills }\end{array}$ & 67.1 \\
\hline
\end{tabular}

The question in the Round One survey process asked the survey participants directly if they believed there were any differences between ERP implementation critical success factors in small or mid-sized versus large-sized organizations. In the Round Two survey, the survey participants were asked to review these responses and to select the five responses that most accurately reflected their viewpoints. Many of the responses appeared to indicate that the differences in ERP implementation critical success factors were largely attributable to 
the limited resources such as capital and personnel available to smaller organizations as compared to their larger counterparts.

\section{Conclusion and Recommendations}

\subsection{Conclusion}

This study resulted in the development of two conclusions, First, while over 22 ERP implementation critical success factors were identified by the survey participants, some factors were mentioned more frequently than others. Specifically, 8 of the 22 ERP implementation CSFs identified by the study participants were mentioned on at least $70 \%$ of the returned surveys. The involvement of senior management/Top management support during ERP implementations was the most frequently mentioned CSF. The survey participants mentioned this CSF on $100 \%$ of the final round surveys. The second conclusion reached is that there does not appear to be much difference in ERP implementation CSFs as they related to small or mid-sized and large-sized organizations. When the survey participants were asked to report ERP implementation CSFs for small or mid-sized organizations, the involvement of senior management/Top management support was mentioned on $100 \%$ of the final surveys. This result was the same as when the size of the organization was not used as qualifier in the research question. Additionally, in small or $\mathrm{mid}^{-}$ sized organizations, the use of skilled, empowered project team as a CSF was mentioned on $100 \%$ of the final survey responses.

This study recognized the involvement of senior management and obtaining top management support during ERP implementation as a CSF. This finding is congruent with the literature reviewed on the topic of CSFs in ERP implementation.

Cliffe(1999) posited that because ERP projects are very risky, senior management should manage ERP projects very closely. The comments from the survey participants were very consistent with comments gleaned from the literature pertaining to the study questions. Panelist A commented for a successful implementation, "strong direction and support from upper management" is required. Thus, there is agreement between the literature presented earlier and the results of this study regarding the involvement of senior management on ERP projects.

\subsection{General Recommendations}

The primary recommendation resulting from this study is that organizations implementing ERP should apply the lessons that the involvement of senior management be assured through all phases of the ERP implementation process. The primary role of senior management on ERP projects, in addition to leadership, may be in the establishment and measurement of project goals and objectives throughout and at the conclusion of an ERP implementation.

Small or mid-sized organizations implementing ERP may do well to learn from implementers of ERP in larger organizations. The research indicated that many of the ERP implementation CSFs in larger organizations are the same as those in small or mid-sized organizations. Due to resource constraints in small or mid-sized organizations as compared to larger organizations, small or mid-sized organizations may benefit from a more focused use of external resources to guide them through the complex process of an ERP implementation.

\subsection{Recommendations for Furture Research}

The study's findings supported many of the findings uncovered in previous research. However, future researches need to focus on the steps necessary to ensure that these CSFs are understood and employed by implementing organizations. Such future research that helps to identify exactly how 
and to what extent senior managers should be involved in ERP implementations may be beneficial.

There have not been many studies in ERP implementations for small and mid-sized organizations. As more of these organizations attempt to implement ERP, more knowledge of implementation in smaller organizations would be beneficial.

\section{References}

[1] Allen, D., Kern, T., \& Havenhand, M (2002). ERP critical success factors: An exploration of the contextual factors in public sector institutions (HICSS-35'02). Proceedings of the 35th Hawaii International Conference on System Sciences 2002: IEEE Computer Society.

[2] Byrod, D. (2002 August). ERP market forecast and analysis, 2002-2006, and first half calendar 2002 review (27794). Retrieved September 6, 2003 from http://www.jdedwards.com

[3] Clayton, M.J. (1997). Delphi: A technique to harness expert opinion for critical decision-making tasks in education. Educational Psychology, 17(4), 373-387.

[4] Cliffe, S. (1999). ERP implementation. Harvard Business Review, 77(1), 16.

[5] Creswell, J.W (2003). Research design: Qualitative, quantitative and mixed methods appraches (2nd ed.). Thousand Oaks, CA: sage.

[6] Davenport, T. H. (1998). Putting the enterprise into the enterprise system. Harvard Business Review, 76(4) 121-131.

[7] Dunham, R. (1998). Organizational behavior: The Delphi technique. Retrieved March 12, 2004, from http://instruction.bus.wisc.edu/obdemo/readings/de plhi.htm

[8] Gordon, T (1994). The Delphi method. Futures research methodology from the AC/UNU Millennium Project Retrieved http://www.futurovenezuela.org/ -curso/5-delphui.pdf

[9] Harreld, H. (2002). Smaller businesses to drive software market. Retrieved November 15, 2003 from http://www.pcworld.com

[10] Holland, C P., \& Light, B. (1999). A critical success factors model for ERP implementation. IEEE Software, 30-36.

[11] Jarrar, Y. F., Al-mudimigh, A., \& Zairi M. (2000). ERP implementation critical success factors - The role and impact of business process management. ICMIT 2000.

[12] Mabert, V. A., Soni, A., \& Venkataramanan, M. A. (2001). Enterprise Resource Planning: Common myths versus evolving reality. Business Horizons, 44(3) 69

[13] Markus, M. L., Axline, S., Petire, D., \& Tanis, C. (2000). Learning from adopters' Experiences with ERP: Problems encountered and success achieved. Journal of Information Technology, 15(4), 245-265.

[14] McLeod, R., \& Schell, G. (2001). Management information systems (8th ed.). Upper Saddle River, NJ: Prentice-Hall.

[15] Parr, A., \& Shanks, G. (2000). A model of ERP project implementation. Journal of Information Technology, 159(4), 289-303.

[16] Scott, J. E., \& Vessey, I. (2002). Managing risks in enterprise systems implementations. Communications of the ACM, 45(4), 74-81.

[17] Summer, M. (1999). Critical success factors in enterprise wide information management systems projects. Proceedings from the America's Conference on Information Systems (1999), http://www.aisorg.net

[18] Teltumde, A (2000). A framework for evaluating ERP projects. International Journal of Production Research, 38(17), 4507-4520.

[19] Verville, J. (2002). Critical success factors affecting the decision process for ERP software. proceedings from Decision Sciences Institute 2002 Annual Meeting. Retrieved http://www.sbear.uca.edu/research/2002/dsi/papers/ 131.pdf

[20] Wah, L. (2000). Give ERP a chance. Management 
Review, 89(3), 20-24.

[21] Wee, S. (2000). Juggling toward ERP success. ERP News. Retrieved October 20, 2000 from http://www.erpworld.org/erpnews/ erp904/02get.html

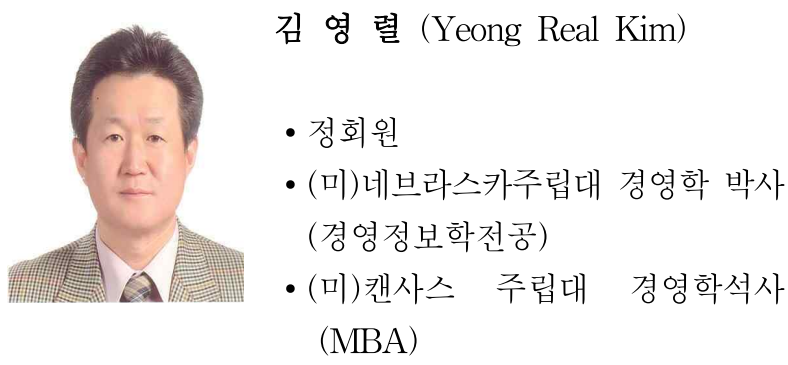

- 현재 : 충북대학교 경영정보학과 교수 